\title{
New Frontiers in Sponge Science - the 2013 Fremantle Sponge Conference
}

On 3-9 November 2013 the 9th World Sponge Conference was held in Fremantle, Western Australia under the theme 'New Frontiers in Sponge Science'. The 186 participants were greeted with a banner tethered to the statue of Eliza in the Swan River (Figure $1 \mathrm{~A}$; list of participants available in Appendix 1). The conference then started with a Welcome to Country ceremony and an icebreaker function at the Western Australian Maritime Museum on Sunday (Figure $1 \mathrm{~B}$ ), followed by 4 days of conference programme at the Esplanade Hotel with 229 presentations (104 full talks, 17 speed talks, 108 posters; Figure $1 \mathrm{C}-\mathrm{F}$ ), a choice of field trips on Friday and a sponge classification workshop at the University of Western Australia on Saturday (Figure $1 \mathrm{G}$ ). This was the second time that the international forum of sponge science convened in Australia, after the 5th International Sponge Symposium was held in Brisbane (Hooper, 1999). Inviting delegates to Fremantle in Western Australia offered access to a diverse mix of history, culture, restaurants and nightlife, with everything within walking distance, and buses, trains and ferries connecting to Perth City. The other reason for meeting in Western Australia was the high potential for exchange between the various sectors of science, academia, application-uptake, industries and commercial use, policy making and regulation. As a consequence, on the first day of the conference one session was dedicated to presentations in the context of industrial activities, fisheries, monitoring and managing sponge habitats (Appendix 2). On the last day of the conference two sessions were given to biotechnology presentations (Appendix 2). Other sessions covered general ecology, phylogeny, symbioses, taxonomy and population biology (sequence according to number of oral presentations; Appendix 2). The programme and the book of abstracts, as well as a media release can be found on the event webpage (Sponge Conference Committee, 2012), and additional accounts were given by Marshall (2013); Mazard (2013) and Schönberg (2014).

The 9th World Sponge Conference differed in several aspects from previous international sponge meetings. During the Fremantle conference parallel sessions were held for the first time, which was controversial. At the two earlier meetings the sponge research community expressed a strong wish to be able to visit every talk, which was previously possible, but at the expense of many delegates not given the opportunity to present a talk. For example, at the 8th Sponge Conference in Girona, Spain, members of the organizing committee excluded themselves from oral presentations, in favour of international and younger delegates. For the Fremantle conference, however, the organizing committee made a decision to allocate a limited number of parallel sessions to accommodate oral presentations requested by every delegate, and in doing so it also reduced the delegate registration costs by finishing the main programme a day earlier than originally planned. Another novelty was realised through a session of 5 minute speed talks, which offered opportunities for rapid communications, which was enthusiastically embraced by a wide range of presenters (Appendix 2). These talks were welcome in the tight schedule and allowed a quick succession of varied topics, but yielded variable feedback. Keynotes delivered by Clive Wilkinson, Bernie Degnan, Ute Hentschel, Manuel Maldonado, Rob van Soest and James Bell were kept to half-hour sessions (Appendix 2), a setting that was received positively. Every evening an opportunity was provided to mingle socially, which included the highly successful Student Meet and Greet Night at the Norfolk Hotel to rapidly integrate students into the science community (Figure $1 \mathrm{H}$ ), the poster session at the Esplanade Hotel (Figure 1I), a very al fresco gathering at Kailis' Fish Market to remember scientists no longer with us (Figure 1J), and the conference dinner at the Fremantle Sailing Club (Figure $1 \mathrm{~K}$ ), during which various awards were distributed (Appendix 2) and not one, but three traditional sponge conference songs were presented (Figure $1 \mathrm{~L}$; event webpage, Sponge Conference Committee, 2012). Field trips on Friday took parties through Fremantle, to Rottnest Island (Figure $1 \mathrm{M}$ ) and the Swan Valley. On Saturday a whole day workshop gave 22 participants the opportunity to learn from nine experienced sponge tutors (Figure $1 \mathrm{G}$ ). Slide presentations and hands-on microscopy sessions demonstrated classical methods in sponge identification and traits typical for sponge orders, and essential databases were introduced (Van Soest et al., 2012, 2016; Hooper et al., 2013; Hall \& Hooper, 2014 and databases these feed into), as well as the concept of sponge functional growth forms that can be used for example when sponges need to be characterized from imagery (Schönberg \& Fromont, 2014; Althaus et al., 2015). As another first, it was possible to upload posters and slide presentations to the Faculty of $1000(2000-2016)$, an open access, Creative Commons license repository that allows citation of otherwise unpublished data for which the author retains copyright. This service was utilized for 34 Internet publications of conference presentations ( 25 posters, 9 talks). Last, but not 


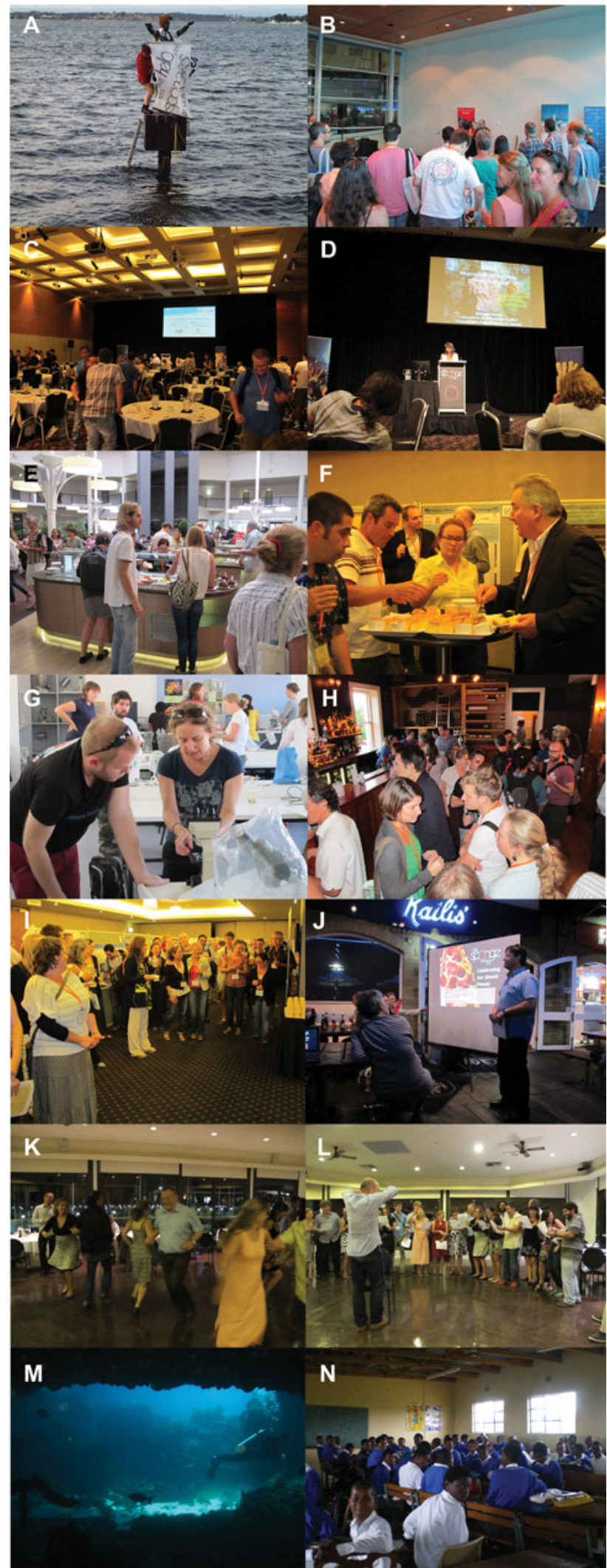

Fig. 1. The 9th World Sponge Conference. (A) Decorating the statue of Eliza, a local billboard in the Swan River for important announcements in Perth. (B) Icebreaker function at the Western Australian Maritime Museum in Fremantle, with Len Collard delivering the Welcome to Country on behalf of the Noongar people. (C) Lecture hall at the Esplanade Hotel in Fremantle. (D) The conference underway, this presentation given by Michelle Klautau. (E) Lunch at the Esplanade Hotel. (F) Coffee break. Alan Duckworth (left) and John Hooper at the table (right). (G) Post-conference least, various unused materials collected after the conference (bags, pens, writing pads, water bottles) were sent to Mgezwa Junior/Secondary School Lusikisiki in Eastern Cape, South Africa to support teaching efforts (Figure $1 \mathrm{~N}$ ). The venue for the next international sponge meeting was elected by a vote from the delegates to be held in Galway, Ireland (June 2017).

Talks and posters covered a wide variety of interests, and the sponge science community attending the 9th World Sponge Conference again proved to be vibrant and engaging, as well as being very good company. Many presenters of the Fremantle conference clearly illustrated the immense importance sponges have in aquatic environments, especially where they are the dominant benthic life form. Nevertheless, they are still under-represented in marine science and have previously been declared a 'neglected group' (Saleuddin \& Fenton, 2006; Schönberg \& Fromont, 2012; Fang \& Schönberg, 2015). Sponge research is also less well rewarded in comparison to work on other benthic organisms (Becerro, 2008). Currently the demand for data on sponge dominated habitats is growing, often with respect to sensitive or changing environments (e.g. Przeslawski et al., 2008; Kenchington et al., 2009; De Mestre et al., 2012). Monitoring and possibly managing sponge grounds or certain sponge species is likely to become increasingly important, and a number of presentations touched on related topics. Interaction between sponges and other biota was a recurring theme, with microbial sponge symbionts having gained a substantial proportion of sponge science. Moreover, based on the high frequency of presentations employing molecular techniques, sponge science clearly appears to be progressively dependent on these approaches, ranging from questions of taxonomy and phylogeny to evolution and physiology, but also being used in the growing field of biotechnology. It was obvious that sponge science has come a long way and that we may now be at a watershed, where we have to consider how 'new frontiers' may or should look like in the future.

\section{SUPPLEMENTARY MATERIAL}

To view supplementary material for this article, please visit http://dx.doi.org/10.1017/S0025315416000096

\section{ACKNDWLEDGEMENTS}

The members of the organising committee of the 9th World Sponge Conference were Nicole Webster (chair), David Abdo, Chris Battershill, Libby Evans-Illidge, Jane Fromont, John Hooper, Christine Schönberg, Shirley Sorokin, Steve Whalan and Wei Zhang. We acknowledge the services provided by Promaco Event Management and the Esplanade Hotel, and are extremely grateful for the following sponsors and supporters of the conference (in alphabetical order):

sponge classification workshop held at the University of Western Australia, Shirley Sorokin is discussing the prepared specimen with Patrick Laffy. (H) Student Meet and Greet Night at the Norfolk Hotel. (I) Poster session at the Esplanade Hotel, Jane Fromont being congratulated. (J) Remembering scientists no longer with us at Kailis' Fish Market. Chris Battershill talking about Patricia Bergquist. (K) Post-conference dinner celebrations at the Fremantle Sailing Club. (L) One of the three conference songs performed after the conference dinner, with Manuel Maldonado directing. (M) Diving during the fieldtrip at Rottnest Island (photograph courtesy Guilherme Muricy). (N) Classroom in the Mgezwa Junior/Secondary School Lusikisiki in Eastern Cape, South Africa (photograph courtesy Megan Botha). 
Australian Biological Resources Study, Australian Department of Environment, Australian Institute of Marine Science (AIMS) and AIMS@JCU, BMT Oceanica, Chevron Australia, City of Fremantle, Co-op Bookshop, F10oo Posters, Flinders Centre for Marine Bioproducts Development of Flinders University, Geoscience Australia, James Cook University (JCU), King Abdullah University of Science and Technology, Marine Drugs open access journal, Murdoch University, Perth Bell Tower, Scientific Committee on Oceanic Research, University of Queensland, University of Waikato, University of Western Australia, Western Australian Department of Fisheries, Western Australian Department of Parks and Wildlife, Western Australian Marine Science Institution, Western Australian Museum. The AIMS Media Team created and managed the event webpage together with the organizing committee. Hai Ngo, Greg Suosaari and Jamie Coquhoun assisted with preparations for the sponge classification workshop. Megan Botha arranged the exchange with Mgezwa Junior/Secondary School Lusikisiki in Eastern Cape, South Africa and sent photographs, and Guilherme Muricy provided the picture from the dive at Rottnest Island. The guest editors thank the editors of JMBA and all contributors to this special volume for their enthusiasm, efforts and patience.

\section{REFERENCES}

Althaus F., Hill N., Ferrari R., Edwards L., Przeslawski R., Schönberg C.H.L., Stuart-Smith R., Barrett N., Edgar G., Colquhoun J., Tran M., Jordan A., Rees T. and Gowlett-Holmes K. (2015) A standardised vocabulary for identifying benthic biota and substrata from underwater imagery: the CATAMI Classification Scheme. PLoS ONE 10, e0141039.

Becerro M.A. (2008) Quantitative trends in sponge ecology and research. Marine Ecology 29, 167-177.

De Mestre C., Maher W., Roberts D., Broad A., Krikowa F. and Davis A.R. (2012) Sponges as sentinels: patterns of spatial and intra-individual variation in trace metal concentration. Marine Pollution Bulletin 64, 80-89.

Faculty of 1000 (2000-2016). F10oo Posters. 9th World Sponge Conference 2013. Available at http://f10oo.com/posters/browse?conferenceld= 253986416. (accessed 12 May 2015).

Fang J.K.H. and Schönberg C.H.L. (2015) Carbonate budgets of coral reefs: recent developments in excavating sponge research. Reef Encounter 30, 43-45.

Hall K.A. and Hooper J.N.A. (2014) SpongeMaps - an online community for sponge taxonomy. Available at http://www.spongemaps.org. (accessed 19 August 2015).

Hooper J.N.A. (1999) 5th International Sponge Symposium, 'Origin \& Outlook'. Memoirs of the Queensland Museum 44, i-ii.

Hooper J.N.A., Hall K.H., Ekins M., Erpenbeck D., Wörheide G. and Jolley-Rogers G. (2013) Managing and sharing the escalating number of sponge 'unknowns: the SpongeMaps Project. Integrative and Comparative Biology 53, 473-481.

Kenchington E., Cogswell A., Lirette C. and Murillo-Perez F.L. (2009) The use of density analyses to delineate sponge grounds and other benthic VMEs from trawl survey data. Northwest Atlantic Fisheries Organization Scientific Council Meeting Document 09/6, Serial N5626, 1-16. http:// archive.nafo.int/open/sc/2009/scro9-006.pdf (accessed 28 January 2016).
Marshall P. (2013) Australian Caribbean Coral Reef Collaboration. Sponge Blog (Squarepants) or 'Should we be managing for sponges?'. Available at http://climateandreefs.org/blog/2013/11/12/sponge-blog-squarepantsor-should-we-be-managing-for-sponges. (accessed 15 September 2015).

Mazard S. (2013) Microbial lifestyle. The 9th International Sponge Conference, 4th-8th November 2013. Available at http://mqgenomics. blogspot.com.au/2013/11/the-9th-international-sponge-conference. html. (accessed 15 September 2015).

Przeslawski R., Ahyong S., Byrne M., Wörheide G. and Hutchings P. (2008) Beyond corals and fish: the effects of climate change on noncoral benthic invertebrates of tropical reefs. Global Change Biology 14, 2773-2795.

Saleuddin A.S.M. and Fenton M.B. (2006) Biology of neglected groups: Porifera (sponges). Canadian Journal of Zoology 84, v, 143-356.

Schönberg C.H.L. (2014) 9th World Sponge Conference and a sponge classification workshop. Reef Encounter 29, 43.

Schönberg C.H.L. and Fromont J. (2012) Sponge gardens of Ningaloo Reef (Carnarvon Shelf, Western Australia) are biodiversity hotspots. Hydrobiologia 687, 143-161.

Schönberg C.H.L. and Fromont J. (2014) Sponge functional growth forms as a means for classifying sponges without taxonomy. In Radford B. and Ridgway T. (eds) The Ningaloo Atlas. Available at http://ningaloo-atlas.org.au/content/sponge-functional-growth-formsmeans-classifying-spo. (accessed 5 April 2015)

Sponge Conference Committee (2012) 9th World Sponge Conference ${ }_{2} \mathrm{~K}_{13}$. Available at http://www.aims.gov.au/web/sponge/home. (accessed 15 September 2015)

Van Soest R.W.M., Boury-Esnault N., Hooper J.N.A., Rützler K., de Voogd N.J., Alvarez de Glasby B., Hajdu E., Pisera A.B., Manconi R., Schönberg C.H.L., Janussen D., Tabachnick K.R., Klautau M., Picton B., Kelly M., Vacelet J., Dohrmann M., Díaz M.-C. and Cárdenas P. (2016) World Porifera database. Available at http:// www.marinespecies.org/porifera. (accessed 2 May 2015).

and

Van Soest R.W.M., Boury-Esnault N., Vacelet J., Dohrmann M., Erpenbeck D., de Voogd N.J., Santodomingo N., Vanhoorne B., Kelly M. and Hooper J.N.A. (2012) Global diversity of sponges (Porifera). PLoS ONE 7, e35105.

\section{Correspondence should be addressed to:}

C.H.L. Schönberg

Oceans Institute at the University of Western Australia, 39 Fairway, Crawley, WA 6009, Australia email: christine.schonberg@uwa.edu.au

Christine Hanna Lydia Schönberg ${ }^{1,2}$, Jane Fromont ${ }^{2}$, John Hooper ${ }^{3,4}$, Shirley Sorokin ${ }^{5,6}$, Wei Zhang ${ }^{6}$ and Nicole De Voogd ${ }^{7}$

${ }^{1}$ Oceans Institute at the University of Western Australia, 39 Fairway, Crawley, WA 6009, Australia, ${ }^{2}$ Western Australian Museum, 49 Kew St., Welshpool, WA 6106, Australia, ${ }^{3}$ Queensland Museum, PO Box 3300, South Brisbane BC, Queensland 4101, Australia, ${ }^{4}$ Eskitis Institute for Drug Discovery, Griffith University, Mt. Gravatt Research Park, Queensland 4111, Australia, ${ }^{5}$ South Australian Research and Development Institute, 2 Hamra Ave., West Beach, South Australia 5024, Australia, ${ }^{6}$ Flinders Centre for Marine Bioproducts Development, Flinders University, GPO Box 2100, Adelaide 5001, South Australia, Australia, ${ }^{7}$ Naturalis Biodiversity Center, 9517, 2300 RA Leiden, the Netherlands 